\title{
As ações afirmativas na Universidade Federal de Sergipe e o reconhecimento social: a face oculta das avaliações
}

\author{
Paulo S. C. Neves ${ }^{a}$ \\ André Faro ${ }^{b}$ \\ Heike Schmitz ${ }^{c}$
}

\section{Resumo}

Neste texto, argumentamos que as avaliações das cotas universitárias precisam incorporar o conceito de reconhecimento social. Se as ações afirmativas que beneficiam alunos de escolas públicas e não brancos nas universidades públicas se tornaram um fenômeno de grande visibilidade, ainda há muito o que se avançar na interpretação dos seus reais efeitos. Desse modo, propomos discutir as mudanças introduzidas por essas políticas no quotidiano da Universidade Federal de Sergipe, dando prioridade à autopercepção dos alunos cotistas e às interações por eles estabelecidas com outros alunos e com os professores. Para isso, utilizou-se uma metodologia que alia métodos qualitativos (grupos focais) com métodos quantitativos (survey). Os principais resultados da pesquisa apontam para o aumento da autoestima dos cotistas e, ao mesmo tempo, para a existência, por razões econômicas e de classe, de tensões entre eles e os alunos não cotistas e, principalmente, entre os professores dos cursos mais prestigiosos.

Palavras-chave: Ação afirmativa. Cotas universitárias. Avaliação. Reconhecimento.

\footnotetext{
a Universidade Federal de Sergipe - UFS, Departamento de Ciências Sociais e Programas de Pós-Graduação em Educação (PPGED) e em Sociologia (PPGS). São Cristóvão, Sergipe, Brasil.

b UFS, PPGPS. São Cristóvão, Sergipe, Brasil.

c UFS, PPGED. São Cristóvão, Sergipe, Brasil.
} 


\section{Introdução}

As políticas de ações afirmativas se tornaram uma realidade incontornável na sociedade brasileira contemporânea. Desde o início da década de 2000, inúmeras experiências têm sido postas em prática em diversas áreas (educação superior, políticas voltadas para populações tradicionais, setores da administração pública, etc.). Dentre estas, foram as cotas universitárias as que certamente geraram mais polêmicas. Com efeito, a adoção, em 2002, de cotas para alunos de escolas públicas e negros nas universidades estaduais cariocas, em 2003 na UNEB e na UnB e, ao longo da década, na maioria das universidades públicas, instaurou um intenso debate no espaço público do país acerca da legitimidade desta medida.

Como se sabe, esse debate veio a desembocar no Supremo Tribunal Federal (STF), o qual, ao julgar uma ação de inconstitucionalidade impetrada pelo Partido Democrata (DEM) contra o sistema de cotas para negros na UnB, decidiu pela constitucionalidade desse sistema de reserva de vagas, facilitando, assim, a aprovação da chamada Lei de Cotas, em agosto de 2012, que estendeu o sistema para todas as universidades federais.

Se o processo, amplamente coberto pela mídia, deu segurança jurídica às universidades que haviam implantado algum modelo de ação afirmativa anteriormente, não pôs fim à controvérsia sobre o tema na sociedade mais ampla.

De todo o modo, esse debate gerou uma grande demanda por avaliações das políticas de ações afirmativas já implantadas e, em especial, das cotas universitárias ${ }^{1}$. Nesse artigo, buscaremos tecer considerações acerca de alguns aspectos do processo de avaliação do Programa de Ações Afirmativas (PAAF) introduzido na Universidade Federal de Sergipe (UFS) a partir de 2010. Argumentamos que uma avaliação das políticas de cotas deve ir além do que comumente é avaliado, a saber: o impacto da chegada dos alunos cotistas para a excelência universitária, medida através das notas e outros índices acadêmico. No âmbito da UFS, essa tem sido a tônica dos relatórios de avaliação do Programa de Ação Afirmativa (PAAF), o qual implantou desde 2010 o sistema de cotas (50\% das vagas para alunos que tenham cursado todo o Ensino Médio e os dois últimos anos do Ensino Fundamental em escolas públicas; destes $50 \%, 70 \%$, ou seja, $35 \%$ do total das vagas, são reservadas para alunos autodeclarados pretos, pardos ou indígenas. Além disso, uma vaga adicional por curso foi criada para alunos portadores de deficiências físicas). Essas proporções foram ligeiramente modificadas para se adequar ao formato da Lei de Cotas a partir de 2012.

1 Ver a esse respeito Brandão (2007), Santos (2013), Santos e Queiroz (2007). 
Por mais essenciais que esses indicadores sejam (e realmente os são), restringir as avaliações a este momento da carreira escolar significa uma capitulação a uma visão instrumental e reducionista das universidades, consideradas apenas pelos ângulos da produção/reprodução das elites e das demandas do mercado de trabalho.

Para transformar essa tendência, necessitamos introduzir nos processos avaliativos uma discussão do quanto a autopercepção dos sujeitos diretamente atingidos é ou não afetada por essas medidas. Dito de outro modo, se o objetivo último de toda política pública é o de buscar uma "vida boa" para a população por ela concernida, as avaliações das ações afirmativas necessitam incorporar a dimensão do "reconhecimento" para dar conta do impacto dessas políticas no contexto atual do ensino universitário no Brasil.

Isto se dá na medida em que, como querem Honneth (2003) e Taylor (1992), a autoestima e a estima social (expressões do reconhecimento) têm um papel importante para a subjetividade dos atores sociais e, por isso, devem ser postas no centro das políticas estatais.

Nesse texto, buscamos nos aproximar dessa temática evidenciando o modo como estas políticas influenciam as percepções dos atores sobre si mesmos, sobre seus projetos de vida e sobre suas expectativas com relação ao futuro. De igual modo, buscamos entender como a implantação das cotas afeta (ou não) o modo como estes atores entendem e explicam as desigualdades sociais.

Propomos, para isso, uma avaliação a partir do "interior": por atores sociais de algum modo implicados na elaboração e na efetivação das políticas afirmativas no âmbito da UFS. Os resultados aqui arrolados foram obtidos através de pesquisas realizadas no contexto do Programa de Ações Afirmativas (PAAF) e junto ao Núcleo de Estudos Afro-Brasileiros (NEAB), órgãos responsáveis pela implantação e acompanhamento das políticas afirmativas ${ }^{2}$. Isso significa que foram professores que se veem confrontados aos impactos das cotas na universidade que buscaram entender o fenômeno. Com isso, muitas informações aqui analisadas foram decantadas a partir do cotidiano docente dos autores desse estudo.

Essa, portanto, não é uma avaliação externa, que se pretende "desinteressada" e distanciada das políticas avaliadas. Sem estar completamente assentada em uma metodologia de avaliação participativa (CARVALHO, 2009), na qual a

\footnotetext{
2 Além disso, as alunas Diana Viturino Santos e Regilane Barbosa da Silva, do curso de pedagogia da UFS, participaram ativamente da coleta dos dados que servem de base para este artigo.
} 
participação dos atores envolvidos ocupa um papel importante ${ }^{3}$, a avaliação ora proposta flerta explicitamente com esse modelo avaliativo. Não apenas pela implicação institucional dos atores como também pelo fato de que sujeitos oriundos do público-alvo das políticas se engajaram, como veremos, em algumas das discussões que servem de base para este texto.

\section{Avaliar políticas públicas, o que significa?}

A pergunta espinhosa que dá título a esse subitem não aparece, em geral, nos textos oficiais de órgãos públicos sobre suas próprias políticas, os quais buscam legitimar suas análises como autoevidentes (FARIA, 2005). Com isso, esquece-se que as avaliações partem sempre de uma perspectiva específica e consideram apenas alguns aspectos da política em tela, o que leva autores como Carvalho (2009) afirmar que

[...] a avaliação tradicional tem sofrido fortes críticas pelo seu carácter externo; pelas suas debilidades metodológicas apresentadas; pela sua preocupação demasiada com a eficiência e, portanto, pela sua incapacidade de apropriar-se do conjunto de fatores e variáveis contextuais e processuais que limitam ou potencializam resultados e impactos (CARVALHO, 2009, p. 87).

Em uma tentativa de dialogar com essa complexa questão, adotamos, no âmbito deste texto, a avaliação como uma complexa teia de ações que visa: a) mensurar os efeitos das políticas (efetividade); b) verificar até que ponto os seus objetivos foram ou não atingidos (eficácia); c) reavaliar alguns detalhes práticos (eficácia); d) verificar até que ponto foram, ou não, acertadas as medidas tomadas (eficiência). Fazemos isso, contudo, a partir de uma perspectiva em que a percepção dos atores sociais que constituem o público-alvo das políticas ganha relevância. Em outras palavras, o objetivo aqui não é apenas de mostrar a repercussão de uma política pública de um ponto de vista de especialistas, mas, sobretudo, tentar entender como essa política funciona e é percebida por seu público-alvo.

Isso é ainda mais importante na área educacional: setor em que os desafios a serem vencidos são imensos - com destaque para as necessidades orçamentárias em todos os níveis - mas no qual também, contraditoriamente, a voz dos que

Que tem como premissa "[...] uma concepção totalizante da avaliação que busque apreender a ação desde a sua formulação, implementação, execução, resultados e impactos. Não é uma avaliação apenas de resultados, mas também de processos. Não é uma avaliação que apenas mensura quantitativamente os benefícios ou malefícios de uma política ou programa, mas que qualifica decisões, processos, resultados, impactos" (CARVALHO, 2009: 88). 
fazem o processo educativo no quotidiano tem pouca audiência na elaboração e avaliação das políticas.

Partimos do ponto de vista de que avaliar políticas públicas é, antes de tudo, levar em conta os seus efeitos qualitativos, os quais ou não se prestam a uma mensuração numérica de forma direta ou traduzem processos tão complexos e lentos que necessitam de um longo período para que seus efeitos possam ser mensurados em termos estatísticos.

Há aqui, certamente, uma questão de temporalidade a ser considerada: entre a implantação e a visualização dos resultados de muitas políticas (inclusive na área educacional) podem se passar anos. Essa temporalidade diferente entre inputs, outputs e outcomes/impacts, usando os termos comuns no chamado modelo lógico (W. K. KELLOGG FOUNDATION, 1998, 2001), faz com que toda avaliação seja uma aposta arriscada, passível de ser refutada à medida que os resultados de uma política amadurecem e se tornam mais visíveis.

Nesta perspectiva, avaliar políticas públicas significa ao menos três coisas diferentes e complementares, a saber:

1. Mensurar os efeitos visíveis e passíveis de quantificação destas políticas; essa é a dimensão mais amplamente praticada e, em geral, baseia-se em dados estatísticos produzidos (os quais, por vezes, são comparados com dados preexistentes) com o fim de perceber o impacto das políticas no cotidiano das pessoas concernidas;

2. Intuir dos dados obtidos, e mesmo em resultados de pesquisas ainda não consolidadas, tendências e influências das políticas públicas a longo prazo; busca-se aqui dar a ver aquilo que ainda só é visto de forma indefinida e em processo de consolidação: as influências não visíveis a um primeiro olhar, ainda com elevado grau de imprecisão. Tais quais espectros ao lusco fusco, não se deixam ver à luz do dia, pois o grau de incerteza e de indefinição dos dados obtidos não o permitem. Isso, não apenas pelo fato de que, em geral, nessa fase os dados são de base qualitativa, mas sobretudo pela própria natureza imprecisa da avaliação quando se pretende ir além dos dados facilmente quantificáveis. Apesar disso, é nessa fase da avaliação que nascem as hipóteses norteadoras de avaliações futuras mais bem armadas com uma base de dados mais vasta.

3. Por fim, toda avaliação visa oferecer as condições para que se possa, a partir dos dados obtidos, prever o que pode vir a ser, os desdobramentos prováveis da realidade social focada pelas políticas avaliadas. Estamos, aqui, no círculo 
da indeterminação, mas de uma indeterminação assentada na busca de indícios sobre as consequências da ação pública, em grande medida iluminada pelas análises realizadas nas duas fases anteriores.

Mensurar, intuir e prever (não necessariamente nessa ordem) constituem não apenas passos importantes nas avaliações de políticas públicas, como também conferem a essas avaliações uma dimensão pública evidente. A visão que propomos aqui das avaliações se aproxima bastante da noção de "avaliação interpretativa" proposta por autores como Greene (2001), Lejano (2006) e Rodrigues (2008), na qual os métodos qualitativos e a busca do sentido que os atores sociais dão às políticas públicas ocupam um espaço importante da análise. Avaliar é, pois, não apenas um ato técnico, mas igualmente um ato público, com repercussões sobre a percepção das políticas públicas pela sociedade.

Quem diz avaliar, diz também intervir sobre a realidade. E isso ocorre independentemente da vontade e dos objetivos de quem avalia, uma vez que a avaliação se tornou uma fase importante no processo de legitimação das decisões políticas no mundo contemporâneo (FARIA, 2005).

Se o uso dos resultados aqui avançados é previsível, ousamos esperar que, por priorizarmos aqui a dimensão da 'intuição' frente às dimensões da 'mensuração' e da 'previsão', este texto é também uma maneira de incitarmos a discussão sobre as cotas universitárias sobre aspectos até o momento pouco usuais e que vão além de seus efeitos imediatos e diretos. Quem sabe assim não estaremos contribuindo para tornar esse debate menos acirrado e maniqueísta?

\section{Avaliação e reconhecimento social}

Do que foi avançado até aqui, percebe-se claramente que atribuímos uma grande importância ao modo como as políticas afirmativas podem interferir na experiência subjetiva os atores sociais implicados nestes programas. Neste sentido, faz-se necessário levar em consideração, em alguma medida, a questão da autoestima e do reconhecimento social dos atores.

A discussão sobre o reconhecimento ganhou centralidade nas últimas décadas, na esteira das mobilizações dos chamados novos movimentos sociais (GOHN, 1997) em que minorias sociais diversas (mulheres, minorias étnicas/raciais, imigrantes, homossexuais, transexuais, grupos religiosos, entre outros) passaram a reivindicar o direito à diferença e a promover identidades sociais particularistas no espaço público. Este processo se traduz em uma dupla via: por um lado, do ponto de vista dos indivíduos, haverá uma sobrevalorização da autonomia e da 
capacidade de agenciamento dos sujeitos (TOURAINE, 1984); e, por outro lado, do ponto de vista coletivo, os Estados buscarão nas políticas voltadas para essas minorias uma nova fonte de legitimação.

Dizer, pois, que o "reconhecimento" se tornou uma linguagem mobilizadora das paixões morais de nosso tempo não seria um exagero. Para o filósofo Charles Taylor, por exemplo, a importância do reconhecimento em nossa época tem a ver com a constituição do self moderno, o qual está assentado no individualismo e na ideia de autorreflexão, o que explicaria o lugar do reconhecimento para a constituição da identidade.

[...] nossa identidade é particularmente formada pelo reconhecimento ou por sua ausência, ou ainda pela má impressão que os outros têm de nós: uma pessoa ou um grupo de pessoas pode sofrer um preconceito ou uma deformação real se as pessoas ou a sociedade que o englobam remetem-lhe uma imagem limitada, aviltante ou desprezível dele mesmo. O não-reconhecimento ou o reconhecimento inadequado podem causar danos e constituir uma forma de opressão, que a alguns torna prisioneiros de uma maneira de ser falsa, deformada e reduzida (TAYLOR, 1992, p. 41-42).

De igual modo, para o sociólogo e filósofo alemão Axel Honneth, o reconhecimento se coloca como fundamental para a identidade individual:

[...] uma ética política ou moral da sociedade deve ser concebida de maneira a englobar a qualidade das relações de reconhecimento asseguradas pela sociedade: a justiça ou bem-estar de uma sociedade se mede pela sua aptidão em garantir as condições de reconhecimento mútuo nas quais a formação da identidade pessoal e, assim fazendo, a realização individual poderão se dar em condições suficientemente boas (HONNETH, 2003, p. 02).

Isto não significa dizer que o reconhecimento seja apenas uma reivindicação de ordem individual; ao contrário, ele está na base das lutas sociais. Nesse sentido, segundo o autor, uma teoria do reconhecimento precisa levar em consideração ao menos três princípios: o amor (no espaço privado), a igualdade (no espaço das instituições que garantem os direitos instituídos) e a solidariedade (espaço das relações sociais interdependentes). Esses princípios não podem ser pensados de forma isolada, pois eles estão intrinsecamente interligados; contudo, a esfera da igualdade e dos direitos tem um peso preponderante nas sociedades 
contemporâneas, pois é através dela que se estabelecem os vínculos entre a autoestima (no privado) e a estima social (no espaço público).

Desse modo, o reconhecimento ganha um estatuto tão importante no pensamento desse autor que passa a ser entendido e manejado como o principal critério de definição de uma sociedade justa em nossa época:

A erradicação da desigualdade não representa mais o objetivo normativo, mas é antes a obtenção da dignidade ou a prevenção do desprezo, a 'dignidade' ou o 'respeito', e não mais a 'repartição igualitária dos bens' ou a 'igualdade material' que constituem suas categorias centrais (HONNETH, 2002, p. 18).

Independentemente das críticas que essas ideias vão receber ${ }^{4}$, torna-se claro que esse debate aborda uma questão central em nossos dias, que se faz presente nos discursos dos movimentos sociais, dos responsáveis pelos órgãos públicos e, também, dos homens e mulheres comuns. Questão igualmente recorrente nos documentos produzidos pelos órgãos internacionais e por agências estatais em diversos países e níveis.

Se, como vimos, o reconhecimento se tornou uma dimensão importante da vida social no mundo moderno, então uma questão que se coloca nas práticas avaliativas é justamente sobre como levar em conta essa dimensão. Dito de outro modo, para mantermos uma coerência com as transformações políticas, culturais e sociais que ocorreram nas últimas décadas em escala mundial, precisamos admitir que uma das questões que devem nortear as avaliações é o quanto as políticas públicas implantadas contribuem ou não para a autoestima do público-alvo, para a estima social que esse grupo goza no seio da sociedade ou para o nível de igualdade que essa política traduz.

Essas indagações compõem um campo reflexivo complexo e envolvem mais dimensões que as discussões específicas de cada política, como se pode notar no caso das ações afirmativas nas universidades públicas: a visibilidade simbólica e midiática das cotas universitárias, por exemplo, fala muito do lugar do debate sobre a discriminação racial na sociedade brasileira e não apenas do mundo universitário em que as cotas são aplicadas.

\footnotetext{
4 A crítica mais pertinente ao paradigma do reconhecimento no âmbito da filosofia política se encontra nos textos de Nancy Fraser (1997, 2000, 2001). Para ela, a importância do reconhecimento na dinâmica social atual não pode nos levar a esquecer a igual importância das lutas pela igualdade material na definição da justiça. Assim, o reconhecimento e a redistribuição são duas dimensões inseparáveis do "justo".
} 
Temos aqui, talvez, uma explicação para entender porque as discussões sobre o reconhecimento são tão pouco presentes nos textos sobre avaliações de políticas públicas. Na medida em que isso implica um certo engajamento moral com aspectos das políticas avaliadas, poucos ousam fazê-lo. Vieira e Tenório (2010), em artigo de reavaliação crítica da obra de Egon G. Guba e Yvonna Lincoln, chegam a uma posição semelhante. Segundo estes autores, Guba e Lincoln pensam a evolução das avaliações das políticas educacionais em termos de gerações (uma primeira geração em que a prioridade seria a mensuração e o diagnóstico; uma segunda geração que surge em torno da Primeira Guerra Mundial pondo como prioridade conhecer os objetivos das instituições; uma terceira geração, que surge nos anos 1960, mais gerencialista, e uma quarta geração, por eles proposta, que seria de cunho construtivista e participativo). Para Vieira e Tenório, apesar do sentido público da avaliação presente nessa quarta geração, ela falha ao não incorporar a questão da sustentabilidade e do devir da sociedade, razão pela qual os autores propõem uma outra dimensão da avaliação, que eles chamam de social: centrada no reconhecimento do outro, no compromisso e no envolvimento do avaliador, que não perde de vista sua condição de cidadão responsável, capaz de realizar análises críticas das políticas a partir de uma perspectiva que leva em conta o devir da sociedade (incorporando assim o paradigma da sustentabilidade).

Apesar das diferenças em termos de perspectivas teóricas e de conceitos utilizados, temos aqui uma preocupação semelhante à que norteia o processo avaliativo por nós proposto, a saber: as avaliações precisam incorporar novas dimensões éticomorais para dar conta do modo como as transformações sociais contemporâneas interferem nas políticas públicas.

\section{Da metodologia}

Com o objetivo de nos aproximar dessa questão, trazemos aqui os resultados de algumas pesquisas realizadas junto a estudantes da UFS ao longo dos últimos anos e que tentam mapear o modo como as cotas intervêm nas relações sociais no interior da universidade.

A primeira dessas pesquisas foi um survey realizado entre outubro e novembro de 2010, com a aplicação de questionários junto a estudantes dos vários campi e centros da UFS. Na época da pesquisa, a UFS era composta por quatro Centros (Centro de Educação e Ciências Humanas - CECH; Centro de Ciências Sociais Aplicadas - CCSA; Centro de Ciências Biológicas e da Saúde - CCBS e Centro de Ciências Exatas e Tecnologias - CCET) e de quatro campi (Campus de São Cristóvão; Campus da Saúde, em Aracaju; Campus de Itabaiana e o Campus 
de Laranjeiras). Os questionários foram tabulados e analisados através de um programa de tratamento de dados estatísticos (SPSS).

Compuseram a amostra 1614 universitários da Universidade Federal de Sergipe (UFS), o que correspondeu a aproximadamente $8,0 \%$ da população de estudantes na época da coleta $(\mathrm{N}=20486)$. Participaram alunos de ambos os sexos e de 74 cursos de graduação nas diversas áreas do conhecimento, estudantes dos Campus São Cristóvão (sede), Campus de Saúde, situado em Aracaju, e os campi de Itabaiana e de Laranjeiras, que fazem parte da expansão da universidade. Vale salientar que a amostra foi construída em termos de representatividade por centros e campi e não por cursos.

As técnicas de coleta de dados foram não probabilísticas, por conveniência e acidental. O delineamento do estudo foi transversal e do tipo survey, visando ao levantamento de opiniões acerca da política de cotas nas universidades públicas e fatores associados. Aplicou-se um questionário fechado com 22 questões, envolvendo respostas em múltipla escolha, dicotômicas ou escala do tipo Likert de 5 pontos. Para o mapeamento dos dados sociodemográficos, questionou-se o sexo (masculino ou feminino), a idade (em anos), a renda mensal familiar (em categorias por quantidade de salários mínimos) e a cor de pele (branco, preto, pardo, amarelo, indígenas e outras referências). Além da autodeclaração da cor de pele, questionou-se a justificativa para ter assinalada uma dada opção (se se percebe assim; pela cor dos pais; outro motivo) e a importância da cor de pele na sua vida.

Quanto aos dados escolares, perguntou-se o tipo de escola que os estudantes cursaram, predominantemente, no ensino médio (pública municipal, pública estadual, pública federal, pública militar ou particular). Questionou-se também se ingressaram pelas cotas (sim ou não) e, em caso afirmativo, que tipo de cota (social ou racial), além do período em que estavam na graduação (entre o $1^{\circ}$ e o $\left.12^{\circ}\right)$.

Os dados foram tabulados e armazenados em planilha eletrônica, tendo sido analisados através de software estatístico. Para a estatística descritiva, obtiveram-se as médias, desvios-padrão e mediana das variáveis ordinais e frequência percentual e absoluta para as variáveis nominais. Na estatística inferencial, aplicaram-se os testes estatísticos do Qui-Quadrado (entre variáveis nominais) e ANOVA one-way, exclusivamente para a relação entre a idade (variável ordinal) e o posicionamento em relação às cotas (variável nominal). O nível de significância adotado foi de $\mathrm{p}<0,05$. 
A segunda pesquisa consistiu na organização de grupos focais (GONDIM, 2002). com alunos cotistas para discutir as cotas e como a adoção desse sistema afetou suas vidas. Para isso, foram organizados 5 grupos, com estudantes dos cursos de Medicina, Direito, Pedagogia, Serviço Social, Química, Economia, Ciência da Informação, Engenharia Civil e Ciências Sociais. As reuniões se deram entre julho de 2011 e maio de 2012 e contaram com a participação de cerca de 32 alunos, variando de grupos com a participação de 4 estudantes a grupos com 16 estudantes. Alguns alunos participaram de mais de um dos grupos focais, mas a maioria participou de apenas um. Nesses grupos, buscouse encontrar apenas os alunos cotistas, pois se queria entender como estes se posicionavam na vida universitária. Os grupos eram formados através de chamadas por e-mail para os interessados, e eram abertos.

Este recorte teve repercussões nos debates: os discursos tendiam a defender as cotas, sobretudo as sociais. Houve mesmo, no último grupo focal, a ida em peso de um grupo de jovens com militância junto às camadas populares, que tentaram monopolizar a palavra em defesa das cotas. Apesar disso, esses grupos foram momentos interessantes para se observar alguns impactos das cotas no imaginário dos alunos da UFS, como veremos a seguir.

Os grupos focais foram organizados em torno de algumas questões norteadoras, as quais correspondiam aos interesses da equipe de pesquisadores (trajetórias de vida, modo como tomou conhecimento das cotas, avaliação da assistência estudantil, entre outras). Nem todos os alunos que participaram eram calouros ou haviam entrado na universidade recentemente. Alguns já estavam na universidade, em cursos menos concorridos e, com as cotas, buscaram mudar para cursos mais concorridos (Medicina e Direito, sobretudo). O que significa dizer que, como veremos mais à frente, estes estudantes trouxeram para o interior dos grupos focais preocupações e uma experiência universitária diferente da maioria dos outros cotistas, ampliando assim a gama de temas debatidos.

Em todas essas fases da pesquisa foi solicitado aos atores que assinassem um Termo de Consentimento Livre e Esclarecido, os quais possibilitam o uso público dos dados aqui arrolados.

Os dados referentes ao perfil amostral estão dispostos na Tabela 1. De modo geral, o perfil foi composto por um número equilibrado entre estudantes do sexo masculino $(55,8 \%)$ e feminino $(44,2 \%)$, o que se manteve quando avaliado o tipo de ingresso na universidade: se cotista ou não cotista. A renda média familiar, em sua maioria, ficou entre 1 e 5 salários mínimos $(58,1 \%)$. Porém, entre cotistas 
uma maioria mais expressiva foi vista nesse grupo (84,3\%), sendo que entre não cotistas a discrepância quanto aos demais estratos foi menor $(50,7 \%)$. Vale salientar que apenas um estudante cotista relatou que sua renda era entre 21 e 30 salários mínimos $(0,3 \%)$, enquanto que entre não cotistas esse montante alcançou 4,3\% (50 participantes). No quesito cor de pele, o predomínio foi de pardos, tanto na amostra geral $(53,4 \%)$, como por ingresso (cotistas $=65,7 \%$; não cotistas $=49,8 \%$ ) (Tabela 1$)$.

O nível educacional de pai e mãe foi a variável que apresentou maior discrepância. Enquanto que entre não cotistas o maior número de participantes tinha pai e mãe em nível secundário $(40,6 \% / 37,5 \%)$, entre os cotistas o mais comum foi pai e mãe em nível primário $(50,0 \% / 40,3 \%)$. Diferença similar também foi observada no nível universitário, pois apenas 3,5\% dos pais e 9,6\% das mães dos cotistas tinham esse nível, enquanto que $28,5 \%$ dos pais e $35,8 \%$ das mães dos não cotistas atingiram tal formação. Por fim, percebeu-se proximidade entre as proporções de cotistas e não cotistas participantes da pesquisa conforme o Centro, com um distanciamento maior no CCSA, em que participaram mais não cotistas $(18,1 \%)$, ao passo que no CCBS a maior participação foi dos cotistas $(31,3 \%)$.

Tabela 1. Perfil dos estudantes segundo o ingresso pelas cotas.

\begin{tabular}{lccc}
\hline Variáveis F\% (n) & Geral & Não Cotista & Cotista \\
\hline Sexo & & & \\
Masculino & $44,2(701)$ & $44,5(543)$ & $45,0(158)$ \\
$\quad$ Feminino & $55,8(886)$ & $55,5(677)$ & $55,0(193)$ \\
Renda (em salários mínimos) & & & \\
Entre 1 e 5 & $58,1(886)$ & $50,7(594)$ & $84,3(285)$ \\
Entre 6 e 10 & $24,8(378)$ & $28,1(330)$ & $13,0(44)$ \\
Entre 11 e 20 & $12,3(188)$ & $15,0(176)$ & $2,4(8)$ \\
Entre 21 e 30 & $3,3(50)$ & $4,3(50)$ & $0,3(1)$ \\
Mais de 30 & $1,5(23)$ & $1,9(22)$ & - \\
Cor de pele & & $13,9(168)$ & $16,9(59)$ \\
Preta & $14,4(226)$ & $49,8(600)$ & $65,7(230)$ \\
Parda & $53,4(839)$ & $24,7(298)$ & $13,7(48)$ \\
Branca & $22,5(353)$ & $8,2(99)$ & $3,1(11)$ \\
Amarela & $7,0(110)$ & $1,1(12)$ & $0,6(2)$ \\
Indígena & $0,9(14)$ & $2,3(28)$ & - \\
Outra & $1,8(28)$ & &
\end{tabular}

Continua 


\begin{tabular}{|c|c|c|c|}
\hline \multicolumn{4}{|l|}{ Continuação } \\
\hline \multicolumn{4}{|l|}{ Nível educacional (pai/mãe) } \\
\hline Não sabe ler & $6,7 / 5,0(103 / 78)$ & $5,6 / 3,9(67 / 47)$ & $10,2 / 8,9(35 / 31)$ \\
\hline Primário & $30,6 / 26,7(472 / 417)$ & $25,3 / 22,8(299 / 273)$ & $50,0 / 40,3(171 / 140)$ \\
\hline Secundário & $39,8 / 38,5(613 / 600)$ & $40,6 / 37,5(481 / 449)$ & $36,3 / 41,2(124 / 143)$ \\
\hline Universitário & $22,9 / 29,8(352 / 465)$ & $28,5 / 35,8(337 / 429)$ & $3,5 / 9,6(12 / 33)$ \\
\hline \multicolumn{4}{|l|}{ Centro } \\
\hline $\begin{array}{l}\text { Educação e Ciências } \\
\text { Humanas }(\mathrm{CECH})\end{array}$ & $16,8(267)$ & $17,0(210)$ & $17,6(62)$ \\
\hline $\begin{array}{l}\text { Ciências Sociais } \\
\text { Aplicadas (CCSA) }\end{array}$ & $16,7(265)$ & $18,1(224)$ & $12,5(44)$ \\
\hline $\begin{array}{l}\text { Ciências Exatas e } \\
\text { Tecnologia (CCET) }\end{array}$ & $32,5(516)$ & $33,8(418)$ & $27,8(98)$ \\
\hline $\begin{array}{l}\text { Ciências Biológicas e da } \\
\text { Saúde (CCBS) }\end{array}$ & $25,0(397)$ & $22,9(283)$ & $31,3(110)$ \\
\hline Itabaiana (CAMPUSITA) & $5,9(93)$ & $5,2(64)$ & $7,1(25)$ \\
\hline Laranjeiras (CAMPUSLAR) & $3,1(49)$ & $3,0(36)$ & $3,7(13)$ \\
\hline
\end{tabular}

Notas: 1 . O somatório dos valores absolutos não perfaz o total de participantes em todas as análises $(n=1614)$ devido a perdas amostrais em cada uma das variáveis sociodemográficas e escolares. Fonte: Dados da coleta em campo na Universidade Federal de Sergipe (UFS) em 2011.

\section{Uma questão fundamental: como os estudantes percebem as cotas?}

A maioria dos estudantes da UFS consultados $(84,9 \%)$ identificou as desigualdades sociais como as principais fontes de injustiça no país, vindo a seguir os que julgavam que esse lugar era ocupado pelas discriminações raciais $(10,3 \%)$ e pelas desigualdades entre os sexos $(2,1 \%)$.

Com relação às desigualdades raciais, $64,3 \%$, consideraram que a situação econômica dos pretos e pardos é pior ou muito pior à situação dos brancos e $69,2 \%$ pensam que isso é injusto ou totalmente injusto, o que explica que, inquiridos sobre a existência de preconceito racial no país, 95,3\% responderam afirmativamente. Quando questionados sobre a possibilidade de mudanças nessa situação de desigualdade, a maioria $(83,2 \%)$ considerou que sim, era possível uma alteração desse quadro.

Porém, apenas 30\% julgavam as cotas, ou outras formas de ações afirmativas, meios eficientes para promover a igualdade entre brancos, pretos e pardos (Tabela 2). 
Tabela 2. Cotas aumentam a igualdade entre brancos, pretos e pardos?

\begin{tabular}{lcc}
\hline Posicionamento & N (1614) & F(\%) \\
\hline Não & 1129 & 70,0 \\
Sim & 485 & 30,0 \\
\hline
\end{tabular}

Fonte: Dados da coleta em campo na Universidade Federal de Sergipe (UFS), em 2011.

Temos, neste ponto, algo interessante, pois o reconhecimento das desigualdades não significa necessariamente a defesa de ações específicas de luta contra elas. Se os dados mostram o quanto a ideia da existência de disparidades entre brancos e não brancos está disseminada na sociedade brasileira, isso não se traduz em apoio às ações afirmativas. É essa aparente contradição que nos ajuda a entender o que está em curso na sociedade brasileira com o debate sobre as cotas universitárias, pois, se por um lado a questão racial aparece como uma fonte de injustiças; e, por outro lado, ela não é vista como mais importante que a questão social, identificada pela maioria como a principal fonte de injustiça do país. E, mais ainda, como veremos, isso indica que, para muitos, as cotas sociais são meios mais eficazes que as cotas raciais para combater as desigualdades, inclusive de cor.

O interessante é que aparentemente foi por meio das cotas raciais que a percepção das ações afirmativas de base social foi aos poucos se modificando na sociedade brasileira. Com efeito, se antes das cotas raciais terem sido introduzidas em algumas universidades públicas a noção mesma de ações afirmativas aparecia como algo de pouca pertinência nos debates públicos (ver a esse respeito, FREITAS, 2012), após 2001, muitos dos que vão se insurgir publicamente contra as cotas de cunho racial vão, ao mesmo tempo, considerar as ações de cunho social mais pertinentes para combater as desigualdades (concomitantemente sociais e raciais) existentes no país.

Isso pode ser visualizado no apoio que a maioria dos respondentes deu às cotas sociais, para estudantes oriundos das escolas públicas: $50,9 \%$ são favoráveis a essa modalidade de cota, em oposição a $35,1 \%$ contrários e a $14,0 \%$ sem posição definida (Tabela 3 ).

Tabela 3. Opinião sobre cotas para oriundos de escolas públicas nas universidades.

\begin{tabular}{lccc}
\hline & N (1614) & F(\%) & Frequência Acumulada \\
\hline Totalmente desfavorável & 264 & 16,4 & - \\
Desfavorável & 302 & 18,7 & 35,1 \\
Sem posição definida & 227 & 14,0 & 49,1 \\
Favorável & 414 & 25,7 & 74,8 \\
Totalmente favorável & 407 & 25,2 & 100,0 \\
\hline
\end{tabular}

Fonte: Dados da coleta em campo na Universidade Federal de Sergipe (UFS) em 2011. 
Contudo, a situação se inverte quando a questão abordada são as cotas para pretos ou pardos. Com $60,1 \%$ de opiniões contrárias às cotas para pretos e $60,9 \%$ opostas às cotas para pardos, percebe-se que a oposição às cotas raciais é elevada entre os estudantes (Tabela 4).

Tabela 4. Opinião sobre cotas nas universidades.

\begin{tabular}{lcccccc}
\hline \multirow{2}{*}{ Posicionamento } & \multicolumn{3}{c}{ Cotas para Pretos } & \multicolumn{3}{c}{ Cotas para Pardos } \\
\cline { 2 - 7 } & $\begin{array}{c}\text { N } \\
(\mathbf{1 6 1 4 )}\end{array}$ & $\mathbf{F ( \% )}$ & $\begin{array}{c}\text { Frequência } \\
\text { Acumulada }\end{array}$ & $\begin{array}{c}\mathbf{N} \\
(\mathbf{1 6 1 4 )}\end{array}$ & $\mathbf{F}(\%)$ & $\begin{array}{c}\text { Frequência } \\
\text { Acumulada }\end{array}$ \\
\hline Totalmente desfavorável & 519 & 32,1 & - & 526 & 32,6 & 32,6 \\
Desfavorável & 452 & 28,0 & 60,1 & 457 & 28,3 & 60,9 \\
Sem posição definida & 248 & 15,4 & 75,5 & 289 & 17,9 & 78,8 \\
Favorável & 211 & 13,1 & 88,6 & 184 & 11,4 & 90,2 \\
Totalmente favorável & 184 & 11,4 & 100,0 & 158 & 9,8 & 100,0 \\
\hline
\end{tabular}

Fonte: Dados da coleta em campo na Universidade Federal de Sergipe (UFS) em 2011.

Isso não impede, no entanto, que uma pequena maioria dos estudantes (52,9\%) considerem que não haverá disparidades entre o desempenho acadêmico de cotistas e não cotistas ou que os cotistas não serão discriminados no interior da universidade $(51,6 \%)$.

Ao que parece, também, as cotas não estão criando identidades raciais cristalizadas. Para a maioria dos estudantes (90,5\%), sua autoclassificação em termos de cor da pele deu-se pela própria cor e não por uma ancestralidade negra perceptível na cor de seus pais (apenas 5,5\% usam esse argumento). Do mesmo modo, embora $97 \%$ declarem estar de algum modo satisfeitos com sua própria cor, $68,3 \%$ não atribuem muita importância à cor de sua pele para sua vida (resposta dada em sua maioria por brancos e pardos, uma vez que a maioria dos pretos $(64,4 \%)$ consideram a cor um elemento relevante de suas vidas) (Tabela 5).

Tabela 5. Tabela cruzada 'cor da pele x grau de importância da cor'.

\begin{tabular}{lcccccccc}
\hline \multirow{2}{*}{$\begin{array}{l}\text { Cor da } \\
\text { Pele }\end{array}$} & & \multicolumn{6}{c}{ Grau de Importância da Cor } & \\
\cline { 3 - 7 } & & $\begin{array}{c}\text { Sem } \\
\text { importância }\end{array}$ & $\begin{array}{c}\text { Pouco } \\
\text { Importante }\end{array}$ & $\begin{array}{c}\text { Medianamente } \\
\text { Importante }\end{array}$ & $\begin{array}{c}\text { Muito } \\
\text { Importante }\end{array}$ & $\begin{array}{c}\text { Extremamente } \\
\text { Importante }\end{array}$ & Total \\
\hline Preta & $\mathrm{N}$ & 66 & 13 & 14 & 49 & 80 & 222 \\
& $(\mathrm{f} \%)$ & $(29,7)$ & $(5,9)$ & $(6,3)$ & $(22,1)$ & $(36,0)$ & $(100,0)$ \\
Parda & $\mathrm{N}$ & 436 & 125 & 95 & 96 & 87 & 839 \\
& $(\mathrm{f} \%)$ & $(52,0)$ & $(14,9)$ & $(11,3)$ & $(11,4)$ & $(10,4)$ & $(100,0)$ \\
Branca & $\mathrm{N}$ & 231 & 73 & 43 & 11 & 6 & 364 \\
& $(\mathrm{f} \%)$ & $(63,5)$ & $(20,1)$ & $(11,8)$ & $(3,0)$ & $(1,6)$ & $(100,0)$ \\
\hline
\end{tabular}

Continua 


\begin{tabular}{|c|c|c|c|c|c|c|c|}
\hline Amarela & $\begin{array}{c}\mathrm{N} \\
\text { (f\%) }\end{array}$ & $\begin{array}{c}67 \\
(61,5)\end{array}$ & $\begin{array}{c}24 \\
(22,0)\end{array}$ & $\begin{array}{c}12 \\
(11,0)\end{array}$ & $\begin{array}{c}2 \\
(1,8)\end{array}$ & $\begin{array}{c}4 \\
(3,7)\end{array}$ & $\begin{array}{c}109 \\
(100,0)\end{array}$ \\
\hline Indígena & $\begin{array}{c}N \\
(f \%)\end{array}$ & $\begin{array}{c}6 \\
(42,9)\end{array}$ & $\begin{array}{c}2 \\
(14,3)\end{array}$ & $\begin{array}{c}5 \\
(35,7)\end{array}$ & $\begin{array}{c}0 \\
(0)\end{array}$ & $\begin{array}{c}1 \\
(7,1)\end{array}$ & $\begin{array}{c}14 \\
(100,0)\end{array}$ \\
\hline Outra & $\begin{array}{c}\mathrm{N} \\
\text { (f\%) }\end{array}$ & $\begin{array}{c}23 \\
(74,2)\end{array}$ & $\begin{array}{c}1 \\
(3,2)\end{array}$ & $\begin{array}{c}1 \\
(3,2)\end{array}$ & $\begin{array}{c}1 \\
(3,2)\end{array}$ & $\begin{array}{c}5 \\
(16,2)\end{array}$ & $\begin{array}{c}31 \\
(100,0)\end{array}$ \\
\hline Total & $\begin{array}{c}\mathrm{N} \\
\text { (f\%) }\end{array}$ & $\begin{array}{c}829 \\
(52,5)\end{array}$ & $\begin{array}{c}238 \\
(15,1)\end{array}$ & $\begin{array}{c}170 \\
(10,8)\end{array}$ & $\begin{array}{c}159 \\
(10,1)\end{array}$ & $\begin{array}{c}183 \\
(11,5)\end{array}$ & $\begin{array}{c}1579 \\
(100,0)\end{array}$ \\
\hline
\end{tabular}

Fonte: Dados da coleta em campo na Universidade Federal de Sergipe (UFS) em 2011.

$\mathrm{Na}$ análise por Centro Universitário, constatou-se, com o teste Qui-Quadrado, significância estatística em todas as análises, revelando que, quanto ao posicionamento geral $\left[\mathrm{X}^{2}(10)=34,755 ; p<0,001\right]$, os estudantes do CCET predominam enquanto desfavoráveis às cotas $(62,1 \%)$ e os do $\mathrm{CECH}$ são os que mais se mostram favoráveis $(41,1 \%)$. Por tipo de cotas, os que são mais desfavoráveis às cotas sociais são os estudantes do CCET $(40,7 \%)$ e os mais favoráveis os do $\mathrm{CECH}(60,7 \%)\left[\mathrm{X}^{2}(10)=26,313 ; p=0,003\right]$. No caso das cotas raciais, em relação às vagas para Pretos $\left[\mathrm{X}^{2}(10)=21,199 ; p=0,020\right]$, os predominantemente desfavoráveis foram os participantes do CCET $(65,2 \%)$ e os que demonstram, em maior proporção, serem a favor, foram os estudantes do Campus Itabaiana (32,3\%). Na cota para Pardos $\left[\mathrm{X}^{2}(10)=29,756 ; p=0,001\right]$ a situação diferiu um pouco, pois foram os estudantes do CCSA que exibiram maior proporção de desfavoráveis $(66,8 \%)$, enquanto que os participantes do Campus Itabaiana foram, novamente, os mais favoráveis $(30,1 \%)$ a essa modalidade de reserva de vagas.

Com relevância particular, efetivou-se a análise da relação entre ser cotista e o posicionamento quanto às cotas, especialmente quanto ao fato de ser desfavorável. Assim, constatou-se significância estatística no posicionamento geral $\left[\mathrm{X}^{2}(2)=212,268 ; p<0,001\right]$, em que os cotistas tendem a ser mais favoráveis $(61,9 \%)$ quando comparados aos não cotistas $(23,1 \%)$. Tal resultado, de certo modo, era esperado, mas cabe apontar que no caso de serem desfavoráveis às cotas, embora tenham predominado os não cotistas (65,5\%), 24,6\% de cotistas, isto é, os que foram beneficiados por essa política, posicionaram-se desfavoravelmente às cotas em geral.

No caso das cotas para escolas públicas, também houve significância $\left[\mathrm{X}^{2}(2)=177,451 ; p<0,001\right]$, sendo que os cotistas $(81,1 \%)$ são mais favoráveis às cotas que os não cotistas (42,5\%). Em sentido contrário, 42,6\% dos não cotistas 
são desfavoráveis às cotas sociais, enquanto apenas 7,7\% dos cotistas assumiram essa posição. Nas cotas para Pretos, também estatisticamente significativa $\left[\mathrm{X}^{2}(2)=153,389 ; p<0,001\right]$, constatou-se que $47,9 \%$ dos cotistas são favoráveis e $67,4 \%$ dos não cotistas são desfavoráveis a esse tipo de cota. Cabe salientar que $33,8 \%$ dos cotistas posicionaram-se desfavoravelmente às cotas raciais para Pretos. Para os Pardos também houve significância [ $\left.\mathrm{X}^{2}(2)=178,684 ; p<0,001\right]$, na qual os cotistas tendem a ser mais favoráveis $(45,0 \%)$ quando comparados aos não cotistas $(14,6 \%)$. Outra vez se pontua que $33,2 \%$ dos cotistas foram desfavoráveis às cotas para Pardos.

No quesito fontes de injustiça do país, viu-se que não houve associação estatisticamente significativa entre o tipo de injustiça e o posicionamento quanto às cotas em geral $\left[\mathrm{X}^{2}(6)=6,393 ; p=0,381\right]$, ou seja, não houve atribuição mais frequente de um determinado tipo de injustiça concomitantemente a ser favorável ou não à política de cotas. Entretanto, no caso das cotas sociais, encontrou-se significância estatística $\left[\mathrm{X}^{2}(6)=16,541 ; p=0,011\right]$, na qual os estudantes que são favoráveis a esse tipo de cota tendem a acreditar que as injustiças do Brasil são derivadas de desigualdades sociais $(51,6 \%)$, enquanto os desfavoráveis creem que as fontes de injustiça advêm da desigualdade entre os sexos (52,9\%). Nas cotas para Pretos $\left[\mathrm{X}^{2}(6)=11,141 ; p=0,084\right]$ e para Pardos $\left[\mathrm{X}^{2}(6)=7,748 ; p=0,257\right]$, não houve significância estatística, isto é, as desigualdades citadas na pesquisa não justificaram o posicionamento favorável ou desfavorável às cotas raciais.

Em seguida, analisou-se a relação entre o posicionamento frente às cotas e a opinião acerca da existência de preconceito no Brasil. Quanto ao posicionamento geral, observou-se significância estatística $\left[\mathrm{X}^{2}(2)=9,099 ; p=0,011\right]$, para a qual os estudantes que acreditam haver preconceito são mais favoráveis às cotas $(32,2 \%)$, quando comparados aos que alegam não existir preconceito $(15,8 \%)$. No caso das cotas sociais, embora limítrofe, não foi detectada significância estatística $\left[\mathrm{X}^{2}(2)=5,446 ; p=0,066\right]$.

Para as cotas raciais para Pretos $\left[\mathrm{X}^{2}(2)=11,113 ; p=0,004\right]$, o resultado foi mais interessante quando analisada a posição desfavorável. Nesse caso, os que negam haver preconceito tendem a serem mais desfavoráveis $(77,6 \%)$, quando comparados aos que o afirmam (59,3\%). Cabe destacar esse último achado, pois, embora aleguem preconceito, quase $60 \%$ são desfavoráveis às cotas raciais. Nas cotas para Pardos, segue-se a mesma tendência das cotas para Pretos. Houve significância estatística $\left[\mathrm{X}^{2}(2)=6,725 ; p=0,035\right]$, em que os que negam o preconceito tendem a ser, na maior parte, desfavoráveis $(75,0 \%)$ e os que confirmam o preconceito $(60,2 \%)$, favoráveis. 
O conjunto desses dados nos mostra algumas mudanças em relação a pesquisas semelhantes realizadas no passado ${ }^{5}$, notadamente com relação a uma maior aceitação das cotas como instrumentos de combate às desigualdades que permeiam a sociedade brasileira. Contudo, os dados nos trazem também a evidência de algumas continuidades: a maior aceitação das cotas sociais em relação às cotas raciais; a descrença acerca do papel das cotas na redução das desigualdades entre brancos e negros e a pouca importância da cor da pele nas relações sociais e na identidade dos entrevistados.

\section{O que dizem os dados qualitativos?}

À luz desses dados estatísticos, realizou-se uma série de pesquisas qualitativas com o objetivo de entender o significado das cotas para os alunos. De uma maneira geral, as temáticas que mais apareceram nesses grupos giraram em torno dos ganhos simbólicos obtidos com a entrada na universidade e, ao mesmo tempo, das dificuldades, entraves e problemas enfrentados na vida universitária.

As questões do "respeito" e da "autoestima" apareceram como recorrentes. Alguns estudantes insistiram no fato de que a entrada na universidade fez com que eles fossem mais respeitados em suas famílias e em grupos dos quais participavam: igrejas, grupos de jovens, etc. Um dos exemplos mais interessantes da pesquisa é o de uma jovem, oriunda de um dos bairros mais violentos e pobres da cidade, que foi aprovada como segunda colocada na classificação geral do vestibular para o seu curso (área de humanidades). No seu relato, o fato de saber que as cotas estavam em vigor foi um elemento importante para a tomada de decisão para participar do processo seletivo do vestibular, o que nos dá uma ideia do efeito psicológico das cotas sobre o imaginário dos jovens oriundos das escolas públicas e de bairros populares, os quais tendem a não ver a entrada na universidade como uma possibilidade factível. Na fala dessa jovem, quando seus familiares souberam que ela havia passado no vestibular, houve uma certa comoção entre os mais velhos, com choros e depoimentos públicos nas reuniões da igreja frequentada por eles. Isso teria ainda transformado essa jovem em uma espécie de modelo para os irmãos e vizinhos menores, que passam a ver os estudos como um caminho possível para pessoas em suas condições.

Então, eu observei, eu senti que fui um exemplo para eles, para os demais, principalmente para os meus primos estudarem e verem a universidade com outro olhar. Não como aquele lugar só para inteligente. Não, todos nós somos inteligentes. Porque a princípio

${ }_{5}$ Ver, a esse respeito, Neves e Lima (2007) e Lima, Neves e Bacelar (2014). 
a universidade é para quem é muito inteligente, para poder passar e tal... Todos nós somos inteligentes. O que diferencia é a batalha que cada um faz, que cada um traça durante o dia a dia. Ai eu percebi que muitos da minha família se sentiram motivados a fazer o pré-vestibular (Fala de aluna cotista participante do grupo focal).

Por sinal, o impacto da entrada dos cotistas na universidade sobre suas famílias aparece em outras falas:

Eu percebi que isso influenciou, percebi que isso influenciou [minha irmã], não só ela, mas como os demais da minha familia também. Eles passaram a pensar que passar na universidade daqui, qualquer um que estava fora tinha condições de passar! Antes das cotas, acho que devido às várias reprovações antes das cotas, [as pessoas diziam] Ave Maria, isso é impossivel, mulher, desista, faça uma outra coisa, faça uma faculdade particular, trabalhando tem condições [de pagar] (Fala de aluna cotista participante do grupo focal).

Isso aconteceu mesmo nos casos de participantes que vinham de famílias que valorizam os estudos como meio de ascensão social, e em que eles não eram os primeiros dos filhos a entrarem na universidade. Nesse caso, o diferencial teria sido o fato de entrarem em cursos de grande concorrência, fato improvável sem a adoção de cotas.

As cotas aparecem nos discursos como uma oportunidade de entrada no ensino universitário, abrindo novas possibilidades de vida e de ascensão social. A desmistificação do acesso à universidade influenciou na decisão de prestar a seleção e cumpriu um papel importante para vencer o complexo de inferioridade, que existia até então. Além disso, o respeito obtido dos outros seria a outra face da valorização de si e dos esforços individuais para entrar na universidade, em oposição aos jovens oriundos das classes mais abastadas, que teriam tido condições de vida mais favoráveis ao estudo:

[...] eu trabalhei como empregada doméstica durante quatro anos, fui babá e foi muito boa a experiência porque minhas patroas me deram um engate para estudar e até hoje eu fico muito grata a elas. Porque, sem a oportunidade que eu tive, eu não conseguiria estudar aqui. Então, eu trabalhei e estudei assim como uma pessoa normal faz, trabalhar e estudar, e o que me levou a estar aqui foi a motivação e meu interesse e a oportunidade [...] A gente precisa 
lutar para conseguir as melhores condições do dia a dia. Então, eu fiz vários vestibulares e não consegui passar. Esse foi o meu quarto e eu dizia, não, eu não vou desistir. Tinha horas que me dava cansaço e queria desistir de tudo porque fiz vários e não conseguia passar, mas as pessoas que acreditavam em mim diziam: 'não, $M$., você vai conseguir você não pode desistir, você tem uma responsabilidade muito grande. Então você não pode desistir dos seus objetivos'. E, então, muita gente me deu muita força e muita energia positiva e eu consegui passar. [...] o diferencial é cada um que faz (inaudível) se tem condições financeiras boas, se não tem, se trabalha, se não trabalha, vai depender de cada um, a valorização se dá pelo que $f a z$ (Fala de aluna da primeira turma de cotas na UFS participante do grupo focal).

Antes de avançarmos com generalizações menos locais, essa pista deva ser seguida com cuidado em futuras pesquisas para que possamos ter dados consistentes sobre o real impacto das cotas nas vidas das famílias de baixa renda que têm membros ingressando nas universidades. Entretanto, não se pode deixar de apresentar como hipótese de trabalho a ideia de que um dos efeitos possíveis das cotas têm sido exatamente o de potencializar mudanças simbólicas, como a que ocorreu no exemplo da jovem citada anteriormente.

Temos aqui um elemento que nos permite pensar que as cotas influenciam espaços que vão para além da universidade, criando uma dinâmica de superação das visões negativas de si não apenas dos cotistas, mas, também, de pessoas que fazem parte do seu meio social.

Isso, contudo, não parece ter levado a reivindicações identitárias atreladas às categorias usadas no sistema de cotas como critério de seleção, a saber, a autoclassificação étnica e o percurso escolar em instituições públicas. Esse é um aspecto importante a ser observado, sobretudo no que diz respeito à questão étnica/racial, por conta dos receios que a introdução das cotas de cunho racial despertasse a emergência de identidades étnicas que levariam ao ódio racial.

Alguns alunos disseram abertamente que foram oportunistas na autoclassificação como afrodescendentes, uma vez que, embora tenham traços não brancos, não se identificavam assim antes do vestibular; fizeram essa escolha, às vezes seguindo conselhos de professores ou coordenadores pedagógicos, por considerarem que a competição seria menos acirrada para os cotistas de escolas públicas autoclassificados como não brancos. 
Aluno: Eu acho que teve uma certa dificuldade... Não das pessoas se declararem negras, assim no grupo lá em que eu estudava, no cursinho era mais fácil. Porque, assim, se declarar cotista é fácil você vai lá e se declara cotista e negro, muito fácil. Tanto mais fácil porque as pessoas sabiam, negras, brancas, independente as pessoas se declaravam negras. E eu senti que até o coordenador do curso lá ele incentivava as pessoas a se declararem cotistas e negras, era mais fácil passar e era mesmo.

Aluna: Mas era uma questão de facilidade, né? Não cria nenhum tipo de constrangimento assim (inaudível) é uma questão que a gente pode levantar... (Diálogo entre dois alunos cotistas participantes do grupo focal).

Dito de outro modo, alguns alunos se autoclassificaram em termos étnicos de modo instrumental: podendo ser socialmente considerados como brancos, foram instruídos por professores, amigos ou familiares a reivindicarem uma ascendência não branca de forma a aumentar as chances no concurso vestibular, sobretudo para os cursos mais concorridos, o que explica, talvez, o fato de que alguns cotistas que se declararam afrodescendentes se mostraram contrários às cotas raciais, como vimos nos resultados do levantamento quantitativo realizado.

[...] se der uma olhada na mídia [...], você pensa que realmente vai ter aquele percentual de negros lá (na universidade). Mas não é assim exatamente como acontece. Tava lembrando aqui que no dia de inscrição eletrônica no vestibular, o coordenador da escola ficou lá no computador, ai o pessoal ia lá para fazer a inscrição e em muitos casos ele até mandava a... [...] O site perguntava se era cotista ou não, se é cotista 'esse eu não sei', ele olhava se a pessoa se declarava cotista racial ou não, se não é cotista vamos lá, pronto eram essas as opções [...] Com isso todo mundo achou bom ser negro, se declarar negro, por isso que nesse instante, nesse momento não teve essa divisão, na verdade mais uma vez eu acho que os brancos acabaram (inaudível) porque se for olhar, no fundo, tem muita gente que fez isso mesmo[...] (Fala de aluno cotista participante do grupo focal).

Deve-se considerar aqui que o que está sendo expresso tem a ver tanto com estratégias em termos de aumentar as chances de sucesso no processo seletivo como também com a polissemia do termo "negro" no Brasil contemporâneo. Os alunos parecem usar o termo 'negro' como sinônimo de 'preto', em um sentido 
diferente do que é usado pelo IBGE e pela maioria dos órgãos governamentais, no qual 'negro' é a soma de 'pretos' e 'pardos'. "Eu me considero pardo [...]. Pardo para mim é o meio termo, é nem um nem outro, aí tem a ideia de todo mundo ser igual...", disse um dos que se sentiam constrangidos por ter entrado pelas cotas étnicas. Vemos, assim, uma certa liberdade no uso das categorias étnico-raciais oficiais.

O que não está longe do que diversos estudos socioantropológicos têm ressaltado no país, em que uma certa manipulação classificatória dos atores sociais é vista como uma das características do sistema racial brasileiro (GUIMARÃES, 2012; MAGGIE, 1991; MOUTINHO, 2004; NOGUEIRA, 1998). É relevante sublinhar que a adoção das cotas na UFS não gerou, aparentemente, tensões raciais. Embora, como veremos, algumas tensões entre cotistas e não cotistas tenham sido identificados pelos participantes da pesquisa, elas não eram vistas como de cunho racial e sim social. Apesar da correlação existente entre desigualdades raciais e de classe no Brasil, os resultados obtidos nas duas pesquisas vão no sentido de mostrar que, para os atores envolvidos, havia uma desvinculação entre esses dois níveis de estigmatização, o social ocupando um lugar mais importante que o racial/étnico nos discursos.

Além disso, ao afirmarem que a autodeclaração racial se deu de forma meramente instrumental, sem implicações mais fortes na sua autoidentidade, esses estudantes estão dizendo que a questão da cor da pele não era vista como importante. Encontramos ecos, neste sentido, dos resultados da pesquisa com questionários que, como vimos, tem como um de seus resultados o fato de que embora a maioria usasse como critério para a autoclassificação a cor da pele, não a consideravam como relevante nas interações sociais. A crer no que disseram alguns estudantes, em parte isso se deve a certa homogeneidade em termos de cor de pele, a maioria podendo se declarar "pardos" seja por conta de histórias familiares de mestiçagem, seja pela cor da pele.

Assim, na fala de uma outra aluna desse mesmo grupo focal, há a ideia de que o preconceito racial era inexistente no curso de Medicina, em parte porque neste não havia 'negros', só pardos.

Acho que não, acho que isso já existe né? Acho que tudo é uma questão de indole; na minha turma não tem preconceito assim de cor né? Nem de origem social nem de nada, apesar que é uma coisa que na verdade negros mesmo são muito poucos. Vamos dizer quase nenhum, na minha turma assim que faz medicina. Apesar do grupo 
ser "C ${ }^{6}$ ", mas negro mesmo... A maioria é parda, a maioria é parda. Branco, branco também não tem, a maioria é parda assim. Mas eu acho que isso não existe não, acho que na verdade a cota apesar de ser étnico-racial, o preconceito maior acho que vai ser mais na parte social mesmo, com relação à econômica assim. Aí você vê pessoas de muito boas condições, pessoas razoáveis e pessoas que estão tendo muito esforço para estar aqui. Acho que o preconceito maior foi assim na minha turma, acho que o maior seria esse assim. Os equipamentos e livros são coisas caras, são coisas que não são acessiviveis para todo mundo entendeu? Então como [inaudivel] aí a pessoa quer ir no congresso e o congresso custa 800 reais, fora passagem, fora os minicursos. Se for fazer uma festa na sala ah que vamos juntar, dai cada um dá 30 reais. Mas 30 reais não é muito dinheiro, não, para fazer um churrasco? Vamos fazer uma coisa mais barata, né? Que dê para todo mundo ir. Acho que a barreira maior é na parte financeira mesmo, acho que é isso [...] (Fala de aluno cotista participante do grupo focal).

Vemos aqui expressa a ideia, que é frequente nos grupos focais, de que as cotas criaram tensões entre os alunos, mas não pelos critérios raciais utilizados e sim por sua dimensão social, que se traduziria em afinidades a partir de determinadas características socioeconômicas (quem tem ou não carros, quem frequenta ou não certos ambientes e espaços sociais, quem vem ou não de determinadas escolas, quem é ou não membro de certas famílias, etc.). Essas tensões não se manifestariam necessariamente em conflitos abertos, mas, sobretudo, em formação de "patotas" e grupos de amigos.

Uma coisa que eu notei é que, assim tipo [...] Não olhei para procurar saber quem era cotista e quem não era, mas se observa na questão social que aqueles grupos... Todas as salas são formadas de grupos. Você percebe que há um grupo dos socialmente com mais grana e outros com menos grana. Você percebe que eles andam em times meio como se fossem separados. Há uma [...] Um fica olhando pro outro, mas, em geral, eles andam assim (Fala de aluno cotista participante do grupo focal).

Temos neste ponto, dito de forma clara, algo que as estatísticas já mostravam. As cotas geraram uma maior mistura social, porém, isso não significou uma maior integração dos membros das classes populares à rede de sociabilidade das

\footnotetext{
6 Cotas para alunos de escolas públicas autodeclarados pretos, pardos e indígenas.
} 
classes mais abastadas. Eis um dos efeitos das cotas que precisam ser melhor explicados e analisados em pesquisa mais amplas, uma vez que, estando o princípio igualitarista na base das ações afirmativas, espera-se que estas sejam meios eficazes de integração social.

Conquanto a questão racial não tenha aparecido como fonte de tensão nesses discursos, ela apareceu como estranhamento. Na voz de um dos participantes da pesquisa, como vimos, isso aparece na constatação de que havia poucos pretos entre os estudantes de Medicina, mesmo após as cotas. A impressão que se tem é que, dadas as características sociodemográficas do estado, cuja população é composta por uma maioria de "pardos" (63\%, em 2010), a introdução das cotas ampliou a presença desse grupo nos cursos mais prestigiosos. Com isso, a população vista pelos alunos como socialmente mais excluída e ausente dos cursos mais concorridos, a população "preta", torna-se invisibilizada. É possível que tenha sido essa compreensão da desigualdade o que tenha constrangido alguns jovens "pardos" ou outros "quase brancos" por terem feito a opção de cotas para alunos de escolas públicas não brancos (negros, na terminologia do IBGE).

\begin{abstract}
Eu acho que há uma certa dificuldade das pessoas para se declararem assim, se elas são cotistas, acho que dá uma certa vergonha para as pessoas. Eu não tenho isso não. Para mim é tanto faz, agora uma coisa, que eu por exemplo, uma coisa que eu já vi uma vez, essa questão racial e empregos e tudo mais; se você é branco e é bom é uma coisa, agora se você é negro, para você ser comparado com essa pessoa tem que ser muito bom, ai rola muito isso, que o negro tem que ter alguma coisa a mais para ser comparado, ai o negro sempre tem uns pontos a menos, ai para ser comparado, não com a... Eu vejo assim dessa forma, mas as pessoas tratam desta forma para ser comparado um com o outro sempre tem que ter algo melhor que o outro (Fala de aluno cotista participante do grupo focal).
\end{abstract}

Não é nosso objetivo - nem temos dados empíricos para fazê-lo aqui - discutir a questão de como a cor da pele interfere na segmentação social no interior da população negra (pretos e pardos) em Sergipe, o que nos levaria forçosamente a discutir os modelos de classificação racial locais e o modo como eles estão integrados na lógica de reprodução das classes sociais. Mas não deixa de ser interessante o fato de que as cotas tenham feito emergir uma discussão sobre preconceito baseado nas classes e, de forma enviesada, na cor da pele entre jovens universitários. 
Em outros comentários que abordaram a relação entre cotistas e não cotistas, as tensões sociais entre os alunos foram consideradas mais fortes, sobretudo nos primeiros semestres dos cursos. Contudo, segundo alguns desses depoimentos, essas tensões teriam diminuído à medida que, com o passar do tempo, os alunos se conheciam melhor e desfaziam os estereótipos. Apesar de não podermos pensar nisso senão ao nível de hipóteses e previsões, não se pode deixar de imaginar que o fato das cotas estarem levando membros da elite a conviverem com estudantes das classes populares, e vice-versa, pode estar criando condições para a superação de uma das formas de discriminação mais presentes em nossa sociedade, que é a discriminação social.

Diversos alunos citaram também as discriminações oriundas de professores em alguns cursos de alto prestígio social. Tais professores usariam expressões desqualificando os alunos cotistas, que não estariam ali por merecimento, e os ameaçariam com uma severidade redobrada. Algumas falas mencionam que, nesses cursos, para determinados professores, os cotistas teriam baixado o nível do ensino, mesmo quando não havia diferenças de notas entre cotistas e não cotistas.

[...] tem um professor, a família dele foi a que fundou a faculdade de medicina, aqui na UFS. Médico bem famoso! Ai o que foi que aconteceu? Na primeira prova o pessoal tirou nota baixa; uma turma de 50 dividiu em duas e uma das duas tirou uma nota muito baixa. Ai ele julgou que aquilo era porque era a turma de cotas. Mas eu acho assim, ele é muito preconceituoso, pois do mesmo jeito que alunos de escola pública tiram notas baixas os alunos de escola particular também tiram [...] mas, o comentário foi somente para os cotistas (Fala de aluna cotista participante do grupo focal).

Parece estar havendo um duplo movimento nos cursos de mais alto prestígio social. Por um lado, com relação aos alunos não cotistas, as práticas discriminatórias tendem a se tornar pontuais e marcadas, sobretudo, por diferenças de classe entre os alunos. Por outro lado, alguns professores desses cursos mantêm uma resistência à presença dos alunos cotistas, nutrindo uma certa desconfiança com relação ao seu potencial de desempenho.

Essa maior resistência dos professores às cotas e aos cotistas tem sido sublinhada em outras pesquisas realizadas na UFS. Assim, em pesquisa junto aos estudantes e professores de Medicina dessa universidade, Oliveira (2013) relata que, em diversos depoimentos colhidos, era perceptível um elitismo muito forte, sobretudo dos docentes, quando estes se referiam aos alunos cotistas. Alguns chegaram a 
justificar que para a população de baixa renda o ideal seriam os cursos técnicos, de fácil e rápida inserção no mercado de trabalho; os cursos que exigiam mais investimentos em termos de tempo e de recursos materiais deviam continuar com processos seletivos mais exigentes, de forma a garantir a excelência acadêmica e a competência dos profissionais formados.

Temos aqui, a expressão de algo que vai além do ethos médico no Brasil, tradicionalmente afastado dos interesses das camadas populares (D'ÁVILA, 2010). Há também um sentimento arraigado de que os cursos de elites são o lugar de reprodução das elites, cabendo aos outros grupos sociais vias profissionais mais pragmáticas.

Isso mostra que no interior da universidade as cotas não são um tema unânime e imune a controvérsias. Questionados sobre o que pensam das cotas, alguns membros do grupo focal se disseram favoráveis às cotas sociais, mas não às cotas raciais, pois seria difícil identificar quem é branco e quem é preto no Brasil.

Acho que foi assim, se bateu muito nessa questão aí: poxa, para que cota né? Vai ampliar o preconceito. Você vai lá declarar sua cor e se você for olhar bem todos nós temos raízes negras. Cara, eu me declaro branca, mas na minha família tem raízes aí, né, negras. Então assim, a discussão foi batida ai também. Alguma coisa nesse sentido de estar reforçando (o preconceito) será que não seria um reforço para isso? (Fala de aluna cotista participante do grupo focal).

Alguns participantes consideravam também que eram os alunos de escolas públicas os que mais tinham desvantagens nos vestibulares, independentemente de serem negros ou brancos.

e uma coisa interessante, a própria universidade ao criar as cotas meio que fica numa tendência preconceituosa., Porque o que é que a gente aprende? Que quando assim, na educação, não tem uma pessoa mais inteligente ou menos inteligente por causa da cor aí a universidade vai e cria um grupo que separa pela cor. Acho que poderia ter cotas por outros motivos, mas não pela cor mesmo, isso não interfere em nada [...] (Fala de aluno cotista participante do grupo focal).

Contraditoriamente, como vimos, alguns membros do grupo que participaram do sistema de cotas disseram terem sidos aconselhados a se autoclassificarem 
como pardos - uma vez que, embora de tez clara, eles apresentavam traços de mestiçagem, pois desse modo eles ampliariam suas chances no processo vestibular. Vemos emergir, assim, algumas das ambiguidades da sociedade brasileira com relação à cor, mestiçagem e discriminação racial. Ambiguidades bem estudadas por diversos autores das ciências sociais e que fazem parte da própria identidade nacional (DAMATTA, 1981).

[...] você tem o negro e o branco, no meu caso, eu estou bem morena com o sol do Nordeste, mas meu apelido era entre os primos lagartixa, que é branca, branca, branca. Então assim, nessa questão assim pessoal se eu for lá [e declarar] parda ou negra é meio estranho, eu sou negra aonde? Você entende assim esta questão? E agora com a questão das cotas, né? A gente tá falando aqui na criação que a mídia deu, nessa questão. Ai alguém vai discutir [inaudível], aí uma pessoa falou assim: eu concordo que a cota venha facilitar o ingresso do aluno de escola pública, levando em consideração essa questão do baixo nivel, baixa renda vamos dizer assim. Dai você diz que até viu isso ai de uma outra forma, mas a questão racial ai ele tava falando com a gente assim. Eu acho que tem um pouquinho do preconceito, por que vai facilitar para o negro, pro índio né, pro pardo, e vai facilitar aí através de cotas isso não é uma forma de preconceituar [sic]? [...] É, entendeu, aí eu fico também, não contra a cota, não, como falei na questão ai né, pois está ai facilitando (a entrada) dos alunos da escola pública, agora assim né, eu fico aí né nessa ideia, pô será que não é meio estranho né, meio constrangedor, o cara, pô para eu passar para eu ter uma chance assim porque eu sou negro? Tá, eu não preciso me declarar que sou negro né, coitadinho né, coisa e tal. Então eu acho assim não sei se quem se declara, de repente não tem ninguém para falar isso né, não sei se o negro se sente assim, sabe eu não sei se esse éo sentimento dele como tava colocando aqui, pô vou aqui me declarar para ter maiores chances assim. Eu não sei se seria isso, mas eu acho que não é legal basear as cotas a partir da questão racial (Fala de aluna cotista participante do grupo focal).

Ao mesmo tempo, de acordo com os discursos dos alunos durante os grupos focais, faltam políticas de permanência consistentes para os alunos cotistas por parte da universidade ou do governo federal. Os programas existentes de ajuda estudantil não são específicos para os alunos cotistas e, na sua maioria, já existiam antes da implantação das cotas. Ou seja, a UFS não ampliou de forma significativa o 
programa de auxílio estudantil, de forma a atender os alunos carentes (cotistas e não cotistas).

Isso estaria afetando as condições de permanência na universidade. Houve certa unanimidade entre os participantes sobre o fato de que a universidade abriu suas portas ao implantar as cotas, mas pouco fez com relação às condições de permanência, sobretudo no que diz respeito a novas bolsas e auxílios em cursos que têm necessidade de materiais e livros mais caros, tais como Odontologia e Medicina.

Agora eu fico vendo também que de certa forma, eu não tenho esses números, mas eu acho que se for olhar de alguns anos para cá quando não existiam as cotas eu acho que tínhamos bem poucos alunos das escolas públicas na universidade [...] Eu acho que se a gente for olhar acho que a cota veio favorecer, facilitar o ingresso, agora a permanência desse aluno nesse universo universitário, essa coisa toda, de repente é uma questão para se trabalhar [...]: não é só facilitar o ingresso desse aluno, mas também favorecer a permanência dele (Fala de aluna cotista participante do grupo focal).

Além de tudo isso, os alunos cotistas afirmam não terem tido muitas informações sobre a universidade ou sobre possibilidade de inserção na pesquisa ou na vida acadêmica. Muitos reconhecem que, ao chegar na universidade se sentiam perdidos, "como peixes fora do lugar", disseram. Este é um aspecto que, como descreve Coulon (2008), não é vivido apenas pelos estudantes cotistas, pois que todos os estudantes levam um tempo para adaptar-se à vida universitária. Contudo, dadas as origens sociais de uma parte dos alunos cotistas, é de se imaginar que as dificuldades de adaptação destes foram maiores que as dos não cotistas.

Como se vê, as percepções dos alunos acerca das políticas de permanência após a introdução das cotas vão quase que unanimemente no mesmo sentido de estudos realizados em diversas universidades públicas do país. Na grande maioria das vezes, as políticas de permanência mudaram pouco em relação ao período anterior às cotas (SANTOS, 2013), o que indica, certamente, que as políticas afirmativas nas universidades públicas estão longe de estarem consolidadas.

\section{7 À guisa de conclusão}

As cotas parecem estar propiciando uma certa valorização simbólica de grupos populares que não se viam como capazes de ingressar em uma universidade pública antes da implantação das reservas de vagas para alunos oriundos de escola 
públicas e afrodescendentes, o que pode, talvez, incitar mudanças no imaginário das classes populares sobre a possibilidade de se chegar às universidades e, mais ainda, sobre o lugar dos pobres na sociedade.

Estariam elas também incitando mudanças no imaginário das elites? Alguns alunos parecem assim pensar, pois, segundo eles, com o tempo as tensões entre os cotistas e os não cotistas diminuíram (mas não desapareceram) nos cursos de Medicina e nas engenharias. Contudo, ainda é cedo para tomarmos essa afirmação como prova de uma tendência mais ampla, pois os próprios alunos apontam situações contraditórias: professores que discriminam e, ao mesmo tempo, alunos que deixam de lado suas visões negativas. O que podemos, entretanto, afirmar a esse respeito é que a introdução das cotas trouxe à tona uma série de questões ainda embrionárias, que precisam de mais pesquisas para serem melhor interpretadas.

Após tudo isso, o que podemos avançar em relação à nossa questão inicial, a saber, de que modo as cotas influem na autopercepção dos estudantes?

A resposta parece ir ao sentido de que as cotas na UFS desencadearam um processo amplo de significações contraditórias. A valorização simbólica de alunos oriundos de escolas públicas, é certo, faz parte da consequência mais evidente. Mas, ao mesmo tempo, a existência de tensões entre alunos cotistas e não cotistas, e entre professores e cotistas, mostram que se a autoestima desses alunos aumentou significativamente, a estima social deles (ou seja, o modo como outros grupos os percebem) parece ter mudado mais lentamente.

As cotas introduziram uma série de mudanças nas universidades públicas e em outras esferas da vida social no Brasil. Contudo, ao mesmo tempo, elas ensejam resistências e provocam problemas ainda não solucionados. Não sem razão, as cotas têm aparecido como um tema central nos debates públicos no país. Estamos diante de um tema que se aproxima da noção de fato social total, proposta por Mauss (2003): um fato que por sua complexidade toca em diversas esferas da vida social e que, por si só, ajuda a compreender muitas das lógicas que estruturam essa sociedade. O que essas ações trarão como mudanças no futuro pode ser apenas intuído.

Contudo, talvez a mudança mais esperada, e que só o futuro poderá dizer se vai se realizar ou não, é a que uma aluna de um dos grupos focais espera que aconteça em relação aos profissionais formados no período posterior às cotas. 
Só queria complementar o que a nossa colega falou [...] que ela disse que o médico por ter vivido né aquela situação ele vai ter bom senso né de proceder e sei lá, o horário dele encerrou e o cara tá passando mal e de repente o caso é grave né, mas acabou o horário, quando o cara faz o juramente de salvar vidas, mas poxa o horário acabou então só o bom senso mesmo sabe? Poxa, o horário acabou, mas bom senso existe, e tem uma pessoa precisando de mim, do meu auxílio. Médico ele não é apenas médico, ele é médico para a sociedade, ele recebe para atuar. E a questão do juiz, por ele ser conservador, ele de repente pode salvar uma pessoa de uma tragédia de ficar 30 anos né preso, de reclusão social. Eu acho que deve haver considerações as agravantes de determinadas situações e aí sim tomar o veredito, condenar ou assumir. Eu acho que isso, resumindo, vai trazer novas opiniões, novos valores, novas é... que já existiam, mas em pouca quantidade entendeu? E isso vai diversificar, vai trazer novos profissionais, com novas caras e vai humanizar vai, sei lá, distribuir essas [...] (Fala de aluna cotista participante do grupo focal).

Há muito mais de esperança aí que de realidade. Nada impede que o contrário do que pensa essa aluna não venha a se produzir, a saber: a captura dos alunos cotistas nos cursos prestigiosos pelos modelos tradicionais das elites brasileiras. Contudo, a simples perspectiva de que algo diferente possa ocorrer no sentido de democratizar não apenas o acesso às universidades, mas também a outros setores da vida social no Brasil, mostra o quanto as cotas universitárias mexem com nosso imaginário e com nosso modelo de sociedade.

Isso nos lembra ainda que o objetivo de toda política pública é (ou deveria ser) o de proporcionar uma "vida boa" tanto para a população imediatamente concernida como também para o conjunto da sociedade, o que nos leva a reafirmar que avaliar essas políticas é não apenas uma tarefa técnica, mas também uma atividade política por excelência. 


\title{
The affirmative action in public universities and social recognition: a hidden face of evaluations
}

\begin{abstract}
In this paper, we argue that evaluations of university quotas must incorporate the concept of social recognition. Indeed, even if affirmative action in public universities for students from public schools and non-whites has become a phenomenon of great visibility, we still have much to advance in the interpretation of its actual effects. Thus, we propose to discuss the changes introduced by these policies into everyday life in the Federal University of Sergipe, giving priority to self-perception of quota students and to the interactions established by them with other students and with teachers. For this purpose, we used a methodology that combines qualitative (focus groups) and quantitative (survey) methods. The main research results point out increased self-esteem of these students and, at the same time, the existence, for economic and class reasons, of tensions between them and the non-quota students, and especially between them and teachers of the most prestigious courses.
\end{abstract}

Keywords: Affirmative action. University quotas. Evaluation. Recognition.

\section{Las acciones afirmativas en las universidades públicas y el reconocimiento social: el lado oculto de las evaluaciones}

\section{Resumen}

En este articulo se argumenta que las evaluaciones de las cuotas universitarias deben incorporar el concepto de reconocimiento social. En efecto, si la acción afirmativa en las universidades públicas a favor de los estudiantes de las escuelas públicas y los no blancos se han convertido en un fenómeno de gran visibilidad, todavía tenemos mucho que avanzar en la interpretación de sus efectos reales. Por lo tanto, proponemos discutir los cambios introducidos por estas políticas en el cotidiano de la Universidad Federal de Sergipe, dando prioridad a la auto-percepción de los cuotistas y las interacciones establecidas por ellos con otros estudiantes y con los profesores. Para esto, se utilizó una metodología que combina métodos cualitativos (grupos focales) y cuantitativos (encuesta). Los principales resultados de la investigación apuntan a un aumento de la autoestima de ellos y, al mismo tiempo, la existencia, por razones económicas y de clase, a las tensiones entre ellos y los estudiantes non cuotistas y especialmente los profesores de los cursos más prestigiosos.

Palabras clave: Acción afirmativa. Cupos universitários. Evaluación. Reconocimiento. 


\section{Referências}

BRANDÃO, A. A. (Org.). Cotas raciais no Brasil: a primeira avaliação. Rio de Janeiro: DP\&A Editora, 2007.

CARVALHO, M. C. B. Avaliação participativa: uma escolha metodológica. In: RICO, E. M. (Org.). Avaliação de políticas sociais: uma questão em debate. 6. ed. São Paulo: Cortez, 2009. p. 87-94.

COULON, A. A condição do estudante: a entrada na vida universitária. Salvador: EDUFBA, 2008.

DAMATTA, R. Relativizando: uma introdução à antropologia social. Petrópolis: Vozes, 1981.

D’AVILA, R. L. A codificação moral da medicina: avanços e desafios na formação dos médicos. Revista Brasileira Saúde Materna Infantil, Recife, v. 10, suppl 2, p. S399-499, 2010. doi: 10.1590/S1519-38292010000600019

FARIA, C. A. P. A política da avaliação de políticas públicas. Revista Brasileira de Ciências Sociais, São Paulo, v. 20, n. 59, p. 97-109, out. 2005.

FRASER, N. Justice interruptus: critical reflections on the post-socialist condition. New York: Routledge, 1997.

. Rethinking recognition. New Left Review, n. 3, p. 107-20, maio-jun. 2000.

. Social justice in the knowledge society: redistribution, recognition and participation. In: KONGRESS "Gut Zu Wissen" Heinrich-Böll Stiftung, 5., 2001. Heinrich-Böll Stiftung. Disponível em: $<$ http://wissensgesellschaft.org/ themen/orientierung/socialjustice.pdf $>$. Acesso em: 10 maio 2014.

FREITAS, M. B. M. Uma década de ações afirmativas: os argumentos que norteiam o debate na mídia entre 2000 e 2010. 2012. 140 p. (Monografia em Ciências Sociais) - Universidade Federal de Sergipe, São Cristóvão, 2012.

GOHN, M. G. Teoria dos movimentos sociais. São Paulo: Loyola, 1997.

GONDIM, S. M. G. Grupos focais como técnica de investigação qualitativa: desafios metodológicos. Revista Paidéia, Riberão Preto, v. 12, n. 24, p. 149-61, 2002. doi: 10.1590/S0103-863X2002000300004

GREENE, J. Dialogue in evaluation: a relational perspective. Califórnia: Sage, 2001. 
GUIMARÃES, A. S. A. The brazilian system of racial classification. Ethnic Racial Studies, v. 35, n. 7, p. 1157-62, 2012. doi: 10.1080/01419870.2011.632022

HONNETH, A. A luta por reconhecimento. São Paulo: Editora 34, 2003.

LEJANO, R. P. Frameworks for policy analisis: margin text and context. New York: Routledge, 2006.

LIMA, M. E. O.; NEVES, P. S. C.; BACELLAR, P. A implantação das cotas na universidade: paternalismo e ameaça à posição dos grupos dominantes. Revista Brasileira de Educação, Rio de Janeiro, v. 19, n. 56, p. 141-63, jan.-mar. 2014. doi: 10.1590/S1413-24782014000100008

MAGGIE, Y. A Ilusão do concreto: análise do sistema de classificação racial no Brasil. 1991. 253 p. Tese (Concurso de Professor-titular) - Curso de Antropologia, Instituto de Filosofia e Ciências Sociais, Universidade Federal do Rio de Janeiro, Rio de Janeiro, 1991.

MAUSS, M. Sociologia e antropologia. São Paulo: Cosac \& Naify, 2003.

MOUTINHO, L. Razão, cor e desejo: uma análise comparativa sobre relacionamentos afetivo-sexuais inter-raciais no Brasil e na África do Sul. São Paulo: EDUNESP, 2004.

NEVES, P. S. C.; LIMA, M.E. O. Percepções de justiça social e atitudes de pré-vestibulandos e universitários sobre as cotas para negros e pardos nas universidades públicas. Revista Brasileira de Educação, Rio de Janeiro, v. 12, n. 34, p. 17-38, jan.-abr. 2007. doi: 10.1590/S1413-24782007000100003

NOGUEIRA, O. Preconceito de marca: as relações raciais em Itapetininga, São Paulo: EDUSP, 1998.

OLIVEIRA, A. H. A. O debate sobre cotas universitárias: itinerários da prática pedagógica na Universidade Federal de Sergipe. 2013, 219 p. Tese (Doutorado em Educação) - Programa da Pós-graduação em Educação, Universidade Federal de Sergipe, 2013.

RODRIGUES, L. C. Propostas para uma avaliação em profundidade de políticas públicas sociais. Revista Avaliação de Políticas Públicas, Fortaleza, v. 7, p. 7-15, jan./jun. 2008. Disponível em: <http://www.mapp.ufc.br/images/revista_aval/ edi\%C3\%A7\%C3\%B5es/9d/artigo-lea_1.pdf > . Acesso em: 14 maio 2013.

SANTOS, J. T. (Org.). O Impacto das cotas nas universidades brasileiras (2004-2012). Salvador: CEAO, 2013. 
SANTOS, J. T.; QUEIROZ, D. M. Sistema de cotas e desempenho de estudantes nos cursos da UFBA. In: BRANDÃO, A. A. (Org.). Cotas raciais no Brasil: a primeira avaliação. Rio de Janeiro: DP\&A Editora, 2007. p. 115-35.

TAYLOR, C. Multiculturalism and the "politics of recognition". Princeton: Princeton University Press, 1992.

TOURAINE, A. Le retour de l'acteur: essai de sociologie. Paris: Fayard, 1984.

VIEIRA, M. C.; TENÓRIO, R. M. Lacunas conceituais na doutrina das quatro gerações: elementos para uma teoria da avaliação. In: TENÓRIO, R. M.; LOPES, U. M. (Orgs.). Avaliação e gestão: teorias e práticas. Salvador: EDUFBA, 2010. p. 53-74.

W. K. KELLOGG FOUNDATION. W. K. Kellogg Foundation: logic model development guide. Battle Creek, 2001. Disponível em: $<$ http://www. smartgivers.org/uploads/logicmodelguidepdf.pdf> . Acesso em: 20 fev. 2014. . Kellogg Foundation: evaluation handbook. Battle Creek, 1998. Disponível em: <https://www.wkkf.org/resource-directory/resource/2010/w-kkellogg-foundation-evaluation-handbook>. Acesso em: 20 fev. 2014.

\section{Informações dos autores}

Paulo S. C. Neves: Doutorado em Sociologia e Ciências Sociais, Bolsista Produtividade (CNPq). Professor da UFS. Contato: pscneves@hotmail.com

André Faro: Doutorado em Psicologia Social. Professor da UFS. Contato: andre.faro.ufs@gmail.com; andre.faro@yahoo.com

Heike Schmitz: Doutorado em Educação. Professora da UFS. Contato: hs.contato.uf@@gmail.com 